\title{
ПОЛЕВАЯ ФОЛЬКЛОРИСТИКА
}

УДК 398.33 (=161.3) (571.14)

DOI 10.25205/2312-6337-2018-2-128-136

\author{
Т. В. Дайнеко \\ Институт филологии СО РАН
}

Записки из Петропавловки:

по результатам экспедиции 2016 г. в Маслянинский район Новосибирской области

В статье опубликована часть материалов, собранных автором в 2016 г. во время фольклорноэтнографической экспедиции в село Петропавловка Маслянинского района Новосибирской области. Представлены фрагменты расшифровки беседы с жительницами села, которые являются потомками переселенцев из Белоруссии и из пограничных регионов и наследниками их фольклорной традиции. Для публикации отобраны сведения о календарных обрядах и песнях села Петропавловка, связанных со Святками, Масленицей, Радоницей, Троицей (описания обрядовых действий, приготовление особой еды и пр.). В опубликованных фрагментах интервью сохранены лексические, синтаксические и фонетические особенности речи информантов. Приводятся вербальные тексты календарных песен. Цель статьи - ввести в научный оборот новые материалы по фольклору белорусов-переселенцев Сибири.

Ключевые слова: фольклор белорусов Сибири, календарные обряды и песни белорусов Сибири, материалы экспедиции, полевая фольклористика.

В июле 2016 г. состоялась комплексная фольклорно-этнографическая экспедиция в Маслянинский район Новосибирской области, проведенная сектором фольклора Института филологии (ИФЛ СО РАН) и Новосибирским областным центром русского фольклора и этнографии (ОЦРФиЭ) ${ }^{1}$. Маршрут экспедиции охватил р.п. Маслянино (районный центр), а также сёла Петропавловка и Прямское. Вообще, как отмечает Н.В. Леонова, «белорусская диаспора... не образовала в сибирском регионе больших ареалов компактного проживания этноса (расселение белорусов в Сибири носит, скорее, островной и рассеянный характер)» [2011, с. 32]. Маслянино, Петропавловка и Прямское относятся к смешанному типу поселений, в которых «белорусы соседствуют с различными группами старожильческого или новопоселенческого населения региона» [Там же].

\footnotetext{
${ }^{1}$ Финансирование экспедиции осуществлялось за счет средств, полученных по Федеральной целевой программе «Сибирская фольклорно-этнографическая экспедиция-2016». В подготовке и проведении экспедиции принимали участие младший научный сотрудник сектора фольклора народов Сибири ИФЛ СО РАН Т.В. Дайнеко (руководитель), научный сотрудник того же сектора Е.Л. Тирон и сотрудник ОЦРФиЭ - зав. отделом экспедиционно-исследовательской работы Т.Ю. Мартынова.
}

Дайнеко Татьяна Владимировна - младший научный сотрудник сектора фольклора народов Сибири Института филологии СО РАН.

Контактная информация: ул. Николаева, д. 8, к. 206, г. Новосибирск, 630090, Российская Федерация.

E-mail: tan-dai@mail.ru; тел.: 8-(383)-330-14-52.

ISSN 2312-6337. Языки и фольклор коренных народов Сибири. 2018. № 2 (36). С. 128-136.

(C) Т. В. Дайнеко, 2018. 
Участники экспедиции ставили своей целью собрать историко-этнографическую информацию от проживающих в указанных населенных пунктах потомков переселенцев из Белоруссии и из прилегающих к ней российских регионов, а также записать сохранившиеся в памяти информантов образцы традиционного фольклора. Последние предполагалось использовать при подготовке второй части белорусского тома академической серии «Памятники фольклора народов Сибири и Дальнего Востока».

В настоящее время особый интерес представляют публикации материалов экспедиций именно в «живом» виде, то есть с сохранением особенностей речи информантов, включением в публикацию не только текстов фольклорных произведений, но и рассуждений информантов о жизни и быте в прежние времена ${ }^{2}$. Это позволяет наиболее выпукло представить локальную фольклорную традицию, оставляя место для интерпретаций исследователей, и вместе с тем ввести в научный оборот архивные материалы. Анализ опубликованного таким образом материала позволяет сделать выводы о степени сохранности той или иной локальной традиции, о ее характерных особенностях, что является важным при изучении фольклорно-этнографических комплексов белорусов-переселенцев [Леонова, 2000, с. 87].

В данной статье публикуются сведения о календарных праздниках, собранные в селе Петропавловка $^{3}$. Но прежде чем приступить непосредственно к материалам, записанным в этом селе, стоит вкратце охарактеризовать и другие этапы фольклорно-этнографической экспедиции 2016 г. в Маслянинский район Новосибирской области.

В районном центре Маслянино образцы белорусского фольклора записывались от участников ансамбля «Петропавловские родники», который появился в 2013 г. и сразу стал одним из самых ярких коллективов области среди исполнителей аутентичного фольклора. Состав участников следующий:

- Валентина Григорьевна Гайдук (Марченко), 1942 г. р.

- Вера Ефимовна Наливайко (Панюшкина), 1943 г. р.

- Петр Денисович Гайдук, 1938 г. p. ${ }^{4}$

Репертуар маслянинского состава отличается от записанного в с. Петропавловка: он обширнее, коллектив звучит более слаженно - сказываются частые репетиции и выступления. Среди записанных преобладают песни лирического жанра.

В селе Прямское в настоящее время приходится констатировать угасание некогда яркой локальной певческой традиции, которое в первую очередь связано с отсутствием преемственности. В последние годы ушли из жизни многие участники фольклорного ансамбля «Прямчаночка» (в годы расцвета в нем насчитывалось 16 человек). Самой большой утратой стал уход Елены Тимофеевны Ананенко (19262015), которая была лидером и запевалой ансамбля.

Для беседы и записи песен в сельском клубе собрались:

- Екатерина Владимировна Прудникова (Киркоро), 1946 г. p.

- Мария Степановна Хомянок (Рапунова), 1936 г. p.

- Лидия Федоровна Новикова (Понуровская), 1946 г. р.

- Вера Викторовна Туняк (Садохина), 1937 г. р.

- Валентина Юрьевна Ковалёва, 1959 г. р., художественный руководитель коллектива.

Из многочисленных в прошлом весенних хороводов села Прямское удалось записать песни «Карагод веду» и «И чего же, Маша, плачешь». От участников ансамбля зафиксированы также сведения о календарных обрядах, о свадьбе.

Отметим, что при единых корнях фольклорные традиции двух соседних сёл - Прямского и Петропавловки - имеют как общие, так и отличные черты. Часть песенного репертуара сёл - общая, при этом тексты песен могут быть одинаковыми, а напевы - различаться. Жители обоих сёл нередко считают, что именно соседи позаимствовали у них песню («Прямцы богато переняли наших песен» - замечание информантов из Петропавловки). Жанр весенне-летнего цикла - хороводы - больше характерен для Прямского (их водили на Радуницу). В Петропавловке же некоторые информанты утверждали, что водить хороводы и вообще веселиться на Радуницу - грех. И в том, и в другом селе молодое поколение

\footnotetext{
${ }^{2}$ Ценность подобного рода публикаций осознается учеными - и этнографами, и фольклористами; в частности, об этом пишет Е.Ф. Фурсова, предваряя издание своих полевых дневников [2012, с. 3]. Автором настоящей статьи уже были подготовлены публикации, находящиеся в русле данной тенденции - см., например: [Дайнеко, 2016, 2017].

${ }^{3}$ Материалы экспедиции хранятся в личных архивах собирателей, а также в архивах Новосибирского областного центра русского фольклора и этнографии и сектора фольклора народов Сибири Института филологии CO PAH.

${ }^{4}$ Отметим, что все они - уроженцы села Петропавловка, переехавшие в районный центр на постоянное место жительства.
} 
говорит уже чисто, без сохранения диалекта, некоторые пожилые люди тоже, по их словам, не любят «гы́канье». Поющие же носители традиции сохраняют особенности белорусского говора.

Село Петропавловка. На подготовительном этапе экспедиции были изучены материалы фондархива Новосибирского областного центра русского фольклора и этнографии, касающиеся Петропавловки. Выяснилось, что три предыдущие экспедиции (1997 г. - Г.В. Любимова, Е. Попок, Т. Куликова, 2003 г. - Л.В. Суровяк, 2013 г. - Т.Ю. Мартынова, Л.В. Суровяк) записывали разные составы исполнителей. И в зависимости от составов принципиально отличается репертуар: 1997 г. - зафиксированы календарные гу́кальные песни, которые ныне никто не поет, 2003 г. - записано много духовных стихов, 2013 г. - преобладает протяжная лирика. Последнее справедливо и по отношению к материалам фольклорно-этнографической экспедиции 2016 г.: подавляющее большинство в репертуаре исполнительниц составляли лирические песни.

Изучение документов показало, что село Петропавловка было основано приблизительно в 1907 г. Село первоначально называлось Укроп, по названию реки, протекающей рядом; впоследствии было переименовано в Петропавловку, по именам первых строителей, братьев Петра и Павла. Первыми жителями стали белорусские (большей частью) и украинские переселенцы из Черниговской губернии и Брянско-Смоленского пограничья. Видимо, смешанный этнический состав населения (в том числе в рамках одного рода) обусловил то, что свои песни жители делят не по этническому признаку, а по родственной принадлежности - «мамина», «отцова», «свекровь пела» и т.п.

Проводником в данной экспедиции для ее участников была Валентина Михайловна Чебакова (в девичестве Гайдук), 1951 г. р., уроженка с. Петропавловка, ныне жительница г. Бердск. Она же стала и информантом: от нее записаны несколько песен ее мамы, Гайдук Нины Макаровны (1924-2002), в том числе редкого жанра - баллады. Валентина Михайловна рассказала о жизни села прежних лет, о своих родителях, родственниках и односельчанах. Именно благодаря ей удалось собрать в селе следующий исполнительский состав (см. также Список информантов в конце статьи):

- Любовь Васильевна Гайдук (Дударева), 1935 г. р.

- Надежда Ивановна Дударева (Цыганок), 1947 г. p.

- Надежда Павловна Ушакова (Филоненко), 1939-2017 гг.

- Евдокия Терентьевна Андрюк (Науменко), 1927 г. р.

Отметим, что, несмотря на пожилой возраст, у всех исполнительниц сохранились сильные голоса. Ярким тембром обладает даже самая старшая из них - Е.Т. Андрюк, которая выводила сложные подголоски в ряде песен.

Встреча участников экспедиции с информантами происходила в течение одного дня 5 . За это время были записаны историко-этнографические рассказы информантов об особенностях труда в первой половине XX в. (в том числе юношеского и детского), о бытовом укладе, о свадебном и похоронном обрядах ${ }^{6}$ В данной статье представлены лишь те фрагменты беседы, в которых информанты рассказывают об особенностях обрядов села Петропавловка, связанных с некоторыми вехами годового календарного круга ${ }^{7}$. К сожалению, таковых фрагментов совсем не много (информанты склонялись больше к пению лирических песен). Тем не менее записаны краткие сведения о проведении Святок, праздновании Масленицы, Радоницы. Значительную часть данной публикации занимают этнографические рассказы о праздновании Троицы. Вероятно, это обусловлено датой проведения беседы - она происходила на следующий день после этого праздника. Также удалось записать несколько календарных песен, в том числе фрагменты весенней гу́кальной (в настоящее время они уже вышли из бытования в данном селе); в данной публикации приводятся словесные тексты песен.

Отметим, что в речи всех информантов сохранилась характерная лексика (йна, яго, смяротное, пирад, тады и пр.) и особенности произношения: фрикативное «г», твердое «ч», «ў» вместо «в», типичные глагольные окончания (например, ляжать, купляють, помре), нелитературные ударения и

\footnotetext{
${ }^{5}$ Встреча состоялась 20 июня 2016 г. в сельском клубе с. Петропавловка. Были сделаны аудио- и видеозаписи беседы, проведена фотосъемка.

${ }^{6}$ Особенно много о свадебном обряде рассказала Н.И. Дударева: от нее зафиксирован последовательный рассказ обо всех этапах свадьбы села Петропавловка, о традиционной одежде, в том числе об изготовлении свадебного венка. Кроме того, в доме Н.И. Дударевой осуществлена фотосъемка предметов быта - украшенных вышивкой (наволочки, рушники) и тканых (рушники, половики). О некоторых чертах похоронного обряда рассказала Л.В. Гайдук.

${ }^{7}$ В основном о календарных обрядах рассказывали Л.В. Гайдук и Н.И. Дударева, остальные участники ограничились небольшими дополнениями.
} 
другие признаки, по которым можно идентифицировать принадлежность информантов к потомкам белорусских переселенцев или выходцев из русско-белорусского пограничья ${ }^{8}$.

Святки. В селе было принято совершать обход дворов с пением поздравительных песен только вечером с 13 на 14 января. «Щёдры петь», как это называлось в Петропавловке, ходили жители села всех поколений, большой компанией - и дети, и молодежь, и взрослые: «кто хоча - иди!» Колядовщиков пускали не только на порог, а «хоть куды! В нашей дяревне - хоть за стол, хоть на кровать (смеются)». Распространено и любимо было ряженье - мазали лицо сажей или раскрашивали красками, надевали вывернутые шубы, завязывали причудливым образом платки, надевали на голову тюки, закрывая лицо, и пр. «А красочки ж были вон тыи кругленькие, а йны ж тякли, знаете, девки. Накрасисся - и оно всё сюды стекло (делает рукали движение с лица и вниз на грудь). Я как-то нарядилась на щёдры, пришла домой, мой Коля сказав: “Иди умыйся, я тебя боюсь” (смеются)» (Н.И. Дударева). Порой колядовщики «безобразию тварыли» - например, крали пельмени, устраивали беспорядок во дворе. Бытовал обряд вождения «козы»: «Под Рожаство хлопцы надявали шубу мехом кверьху, делали рога». Была и песня «под козу», но ее информанты не вспомнили. Дети бегали по домам родственников за подарками, в основном съедобными: «побегишь по дядьках, по тётках, штоб хто яечко даў. Побегу к дядьку, [родители спросят:] - Ты куды? - Побегу к дядьку, он шче мне яечко не даваў. - То мамкин брат или папкин. А теперь пошли дятей по тое яечко! (смеется)» (Н.И. Дударева). «Нихто не ходя никуды...» (Л.В. Гайдук). «Святое дело было - к родственникам сбегать за яйцами» (В.М. Чебакова). «А хрёстная мне до самой смерти носила яйцы. Етой такий закон был - ужо хрёстная всегда принесе табе яец» (Н.И. Дударева). При опросе Т.Ю. Мартыновой по списку песен, записанных в предыдущих экспедициях, в числе прочих была песня «Ти дома ли, дома пан хозяин...» - ее информанты не спели, но сказали, что знают: «ну, ета шчёдры, знаем!» Традиция поддерживается информантами и в настоящее время: «А я и сейчас по дво́ре хожу. Каждый год! Пшеницу - в карман [и пошла]» (Н.И. Дударева). Вместе с Л.В. Гайдук они проговорили начало текста песни-посевания: «Сею-сею, посеваю, с Новым годом поздравляю. / Рожь и пшаницу, всякаю пашницу. / На паличке сундучок - подавай-ка пятачок, / Налетай-ка... што бочок, што стаканок хто што придумае!» Также прозвучало начало щедровки: «Щодер-бодер, а хозяин злодер, / А кому добрый... - што хотели [пели]!». Также во время обхода дворов пели частушки: «тут пийсят грамм нальют, там нальют - и частушки пошли». Интересен комментарий относительно алкоголя: «А када мы были молодые, наше поколение... Теперь жа ети не умеють выпивать: напьются - и на работу не идуть. А у нас это всё просто було́: мы погуляем - и корову шли доить, и телят поить...» (Н.И. Дударева). На посиделки или вечерки молодежь собиралась обычно «по дома́х».

На Масленицу, по рассказам информантов, главным ритуальным действием было сжигание чучела на речке - этим занимались только парни.

Обнаружилось интересное пересечение масленичного и свадебного песенного репертуара. В.М. Чебакова напомнила всем песню, которую затем и спела вместе с Л.В. Гайдук и Н.И. Дударевой. Песня эта масленичная по всем характеристикам (текст, типовой масленичный напев), но в Петропавловке она исполнялась на второй день свадьбы - вероятно, из-за веселого и юмористического характера, подходящего для свадебного пира, и текста на семейную тематику. «На другий день [поют эту песню], в первый день не пели таких», «вот все пляшут и поют»:

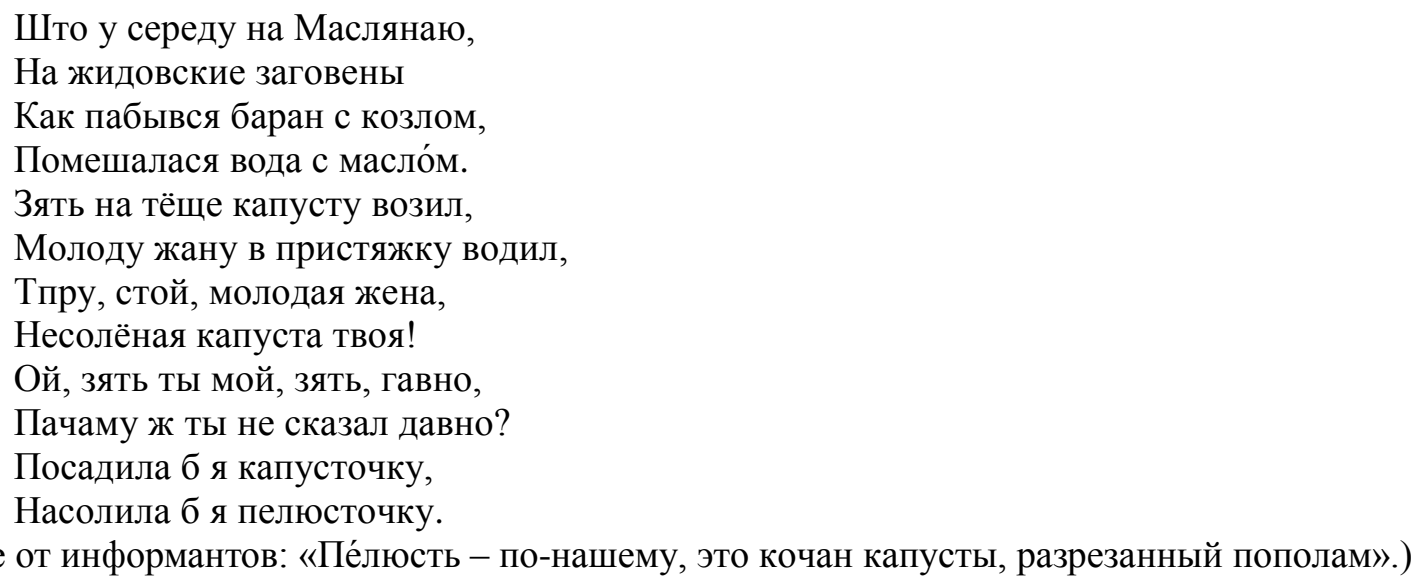

(Пояснение от информантов: «Пе́люсть - по-нашему, это кочан капусты, разрезанный пополам».)

\footnotetext{
${ }^{8}$ В сделанной нами письменной расшифровке беседы далеко не все из этих особенностей нашли отражение: фрикативное «г» следует подразумевать по умолчанию, некоторыми чертами фонетического строя пришлось пожертвовать ради удобства восприятия текста читателем.
} 
Н.И. Дударева показала с помощью всех присутствующих на встрече, как именно в хореографическом отношении исполняли данный хоровод: надо было встать друг за другом, положить руки на плечи соседу спереди и идти вперед в темпе песни, притоптывая, немного дробя ногами. Она же спела в конце встречи еще одну песню на такой же напев:
Што у середу на Маслянаю,
На жидовские заговены
Парасёнок яичка изнёс,
На высокую паличку занёс.
А глухий та подслушивая,
А слепый та подглядывая,
А безрукий яечко украў,
А безногий в поход побежаў.

«- А когда пели? - Это пели на други́й день свадьбы, когда уже вси... - А почему тогда Масленица? - Ну вси равно пели».

Затем были проговорены варианты текста. Н.И. Дударева вспомнила такие строки: «Побился баран с козлом, / Помешалася вода с молоком. - С песком! - исправляет Е.Т. Андрюк. - Хто што пел», - примирительно поясняет Н.И. Дударева.

Пасха. Радоница. Говоря о том, что «родительский день [был] отдельно» (см. ниже), Л.В. Гайдук имела в виду Радоницу. «- А когда был этот родительский день, после Пасхи? - Да. - Его называли как-то или это был просто “родительский день” и всё? Радоницей не называли? - Вот так и называли - Радоница. [Она] была во вторник после Пасхи. В родительский день [на кладбище] ходили уси́! И могилки застилали скатертями, вешали етыя рушники вышиваныя на хрясты. Тада ж были хрясты. Это ж тяперь ужо памятники всё. Сплошь памятники, памятники и памятники. А тада ж было хрясты и хрясты. Вот у кого скольки покойников, прино́шают скатерстя, застилають каждый сваих. - А где расстилают, на могилках прямо? - Прямо на могилку застилають. А угощение стано́вють около хреста. На могиле становют, да, коло хреста становют. Вот сколько мы времени там побыли́, на могилках, походили там, посидели - собираемся уси́ обедать. Собираемся, кому близко друг к другу. Вот собираемся... тады кру́гом садимся, у кого што ёсць - прино́шаем и садимся обедаем. Кучай садимся, сколько там чалавек - я не знаю, у которых могилки близка. - Где-то между могилками садитесь? - Да, расстилаем скатерку, изно́шаем обед увесь с могилок и обедаем уси́ умести. И всё. Пообедали, и всё, и пошли. - А какое-то особенное угощение готовили на Родительский день? Яйца обязательно носили на кладбище? - Обязательно яйцы! Блины стряпали. Хто што стряпае. Хто бараньки. Бараньки стряпали, моча́ли в сметану. Я, например, тесто мешаю на простаки́ше (простокваше. - T. Д.). Замешала... Раскатала, нарежу на небольшие кусочки. Раскатала, на сковороде у мене постно масло кипить. Я поклала бараньки еты, она щас же подымаются, я перевернула - оно всё уже готовое. В сметану помоча́ла - баранька готова. [Пока] пекла, в чашку склада́ла, чтобы они простыли. А тады помоча́ла - в другую покла́ла чашку».

Особых песен, исполнявшихся на Радоницу, информантка вспомнить не смогла, посетовав на разрушение со временем преемственности традиции; отметила лишь, что на кладбище положено было петь «молитвы». «- А старые бабушки пели [на кладбище] какие-то особые песни - не молитвы, а другие? - Ни разу не слышала. Ето надо тожа петь, молебные песни. А другие - не знаю, милая моя... У нас уже тада попримёрли старые, а молодые ни черта́ не знають и не знали... А што бы я пела, када я не знаю? Мене никто не учил! Мать моя помёрла рано, все помёрли рано... Свякруха моя никада не пела ничо́го и не рассказывала ничо́го. Это ж када́сь-када́сь (когда-когда, то есть очень давно. - T. Д.) былó, када́сь-када́сь было́, деўки...» Однако отметим, что эта же информантка затем вспомнила и спела хороводную песню «Карагод веду, я не выведу», слышанную ею от своей матери, которая исполнялась в пасхальный период (см. ниже).

Tроица. По словам Л.В. Гайдук, «пирад Троицей была Духова́я суббота». В этот день обязательно надо было собрать в лесу зелени, которой украшали жилище: «У субботу ходили у лес, рвали траву кустовую - кустами которая расте. Бывае полевая мята - она пахне уку́сно, и вот мяту ету рвали. Цвяты - аганьки, мяду́нки, всякие цвяты рвали. Прино́сили дамоў, за стол ки́дали. Столы в угле так все стояли, а там кругом лаўки - дык за стол клали туды траву, под стол бросали». Траву не убирали из дому несколько дней, дожидаясь, пока она полностью высохнет, затем собирали в холщовые сумки и хранили в сухом месте, ежегодно пополняя запас, чтобы, когда потребуется, использовать ее в похоронном обряде: «Каждый год собирали [траву] у Духову́ю субботу. И йна высыхала, тая трава, и ету траву собирали и склада́ли у сумку - ну, холщовые были сумки, шитые, из хольста. Подвешивали 
куды-не́будь и хранили. Всё время. Могла хоть сколь ляжать. Штоб она только... вода на ей не шла, не попадала, штоб она не мокрая была. Чтобы када покойник помрэ, ету самую траву - у подушку. Шили подушку, ната́лкали [в нее] траву ету сухую и подушку - под галаву́ [покойнику] клали». Посещений кладбища накануне Троицы информантка не припомнила, утверждая, что «родительский день был отдельно».

Непосредственно в день Троицы в Петропавловке принято было ходить в лес большой компанией и устраивать там гуляния - качаться на специально устроенных к этому дню качелях, плести венки, веселиться. Л.В. Гайдук описывает, как происходили праздничные гуляния в конце 1940 - 1950-х гг. Согласно ее рассказу, в это время троицкие песни уже исчезли из активного бытования, то же самое произошло с большинством ритуальных элементов, а сохранившиеся утратили свою магическую функцию и превратились в развлечение. «Тады, деўки, жили дружно. Деревня была большая. - Сколько дворов было? - Ой! Я не посчитаю, сколько тут дворов было́. А деревня была здоровенная. Молодёжи было много, деўки, народу было многа! Ой, як Троица - стольки народу! В лес идуть... Одна толпа идёт домой, другая - идеть в лес. И парни, и деўки, вси подряд шли. - А пели что-то по пути, пока шли? - Уже, милая моя, не помню. Я вот сколь ходила - дак не пел никто. - А что там делали? - Качались на качели. Хохотали. Што делали - ничо не делали... - А веночки плели? - Плели веночки, из цвятов. Аганьки рвали, меду́нки рвали, всё рвали и вянки плели. - А потом что с этими венками делали? - А ничо́го! Наденем на ду́рневу на галаву́, и хорошо (смеется). - А вокруг березки что-нибудь делали? - Нет, ничего не делали. - А к речке ходили потом? - Не, к речке не ходили ни разу. Просто: пришли в лес, на полянке там посмеялись, покачались на качелях и снова пошли домой. Домоў пришли, тут что поели и снова пошли. Вот и ходили взад-вперед (смеется)». Особенной еды, по словам информантки, в день Троицы не готовили по причине всеобщей бедности: «- А что в Троицу готовили? - О господи, да у кого что былó! Раньше ж что было́ богато... Босяка́ ходили, голяка́...»

Н.И. Дударева тоже вспоминает катания на качелях как центральный элемент празднования молодежью Петропавловки Троицы: «Вот сейчас Троица - никуды не ходют. А раньше на Троицу хлопцы делали загоде́и (заранее. - T. Д.), за два, за три дни качели, и ужо деўки собираются и на качелях на тых [качаются]. До тых пор накачаисся, што идешь оттый... (трясет головой, изображая головокружение). Высо́ко! Хто боится... У нас вот одна упала, Нюра, и убилась: полежала - и всё». На вопрос о том, какие еще действия были характерны для этого дня, она ответила: «Ничо́го не делали - ни пили́, ни бала[ва]лись!» Ни одной троицкой песни исполнить она не смогла, но, по ее словам, пение было обязательным для этого дня: «-А песен не пели? - Почаму? Тудысь и пели! - А что пели? - А такие вот старынные раньше пели всякие».

В понедельник после Троицы наступал Ду́хов день (в православном календаре праздник также носит название Понедельник Святого Духа). Представления о нем жителей села Петропавловка находятся в русле общей восточнославянской традиции: «- Вчера была Троица. А сёдни в нас праздник - земля именинница... Сёдня земля именинница - нельзя трогать яе. - Это так мама говорила? - И в церкви гово́рют так. Поп так гово́рит. - А в Петропавловке же нету храма? - Нету. В Маслянино [есть]. Но я в яго не езжу. И родители, покамесь у нас храма не было́ отут, в Маслянином, и родители мои не ездили. Мои родители рано помёрли - матке писят годов було́, а батьку - шийсят» (Л.В. Гайдук).

Календарных песен в селе Петропавловка во время экспедиции 2016 г. было записано не много. Кроме тех, что уже приводились, были спеты еще несколько. Среди них есть ценный образец весенних гу́кальных песен, исчезнувших в настоящее время из бытования в селе. Рассказывает В.М. Чебакова: «- Вот песню я от мамы слышала. Гу́калка, это гу́калка настоящая. - Ну дык хто умее гукать? Мы не умеем... - Я два куплета знаю, могу спеть. Не знаю только, в каком месте гу́кать надо. - Йны (они - имеются в виду фольклористы, делающие запись. - T. Д.) на́йдуть, йны добавють» (все смеются). Далее В.М. Чебакова поет (с гуканьем), некоторые из информантов подтягивают:

Ой, что же я наробила

Ой, что же я натворыла.

Хало́стаго позабыла,

Женатаго полюбила. Ууу!

«- А дальше? - А дальше я еще один куплет знаю. - А почему ты ее всю не выучила? - А мамы уже нету, и не выучила».

Он жанатый, ни халостый,

У яго есь жана в доме,

У яго есь жана в доме,

Да йще дробные дети. Ууу! 
Продолжение песни В.М. Чебакова проговаривает: «Всё, третий куплет не знаю. А там дальше поётся... Она его спрашивает: “Милый, а что же мне дальше делать?” Он говорит: “Видишь речку? На той стороне камень. Вот перепрыгни - и об камень головою!'”. Остальные информанты соглашаются, что это песня старинная - «ето шче наши матки пели», и единодушно утверждают, что «ети гу́калки пели тольки вясной, гу́калки строго вясной». При этом петь их можно было как в деревне, так и на открытом пространстве - в поле или в лесу: «- А весной где-то на поле их пели? - Ну да. А шче [в лес] пойде, нагу́кае там, аж лес раздира́е».

От Л.В. Гайдук был записан (в неполном виде) весенний хоровод «Карагод вяду, я не выведу...» Информантка рассказала, что «карагод пели старые люди на Паску», а песню «Карагод веду» она помнит от матери, которая хорошо пела. По воспоминаниям Н.И. Дударевой, весенние хороводы могли сопровождаться гу́каньем: «Моя мамка шче пела вот етые карагоды, а потом шче так: ууу!» (пропевает возглас напряженным тембром в высоком регистре). Три куплета хоровода Л.В. Гайдук спела одна, так как больше песню никто не знал:

\section{Карагод вяду, я ни вывяду \\ Вой ли, ой люли, я ни вывяду. \\ По себе дружка я ни выберу, \\ Вой ли, ой люли, я ни выберу. \\ Вот я й выберу, дак я старага, \\ Дак я старага, да невдалага.}

Интересно, что при очевидном разрушении традиции информанты хорошо осознают приуроченность песен и помнят о ней. На предложение исполнить хороводную песню «Ты утица луговая», записанную в их селе, ответили: «Яе шчас не пею́ть. Это наша песня, но яе поють тольки вясной» (Н.И. Дударева). Затем информанты всё же исполнили этот длинный хоровод полностью, вчетвером (два куплета запевала Н.П. Ушакова, затем - Л.В. Гайдук, она же знала весь текст, выводила Е.Т. Андрюк):

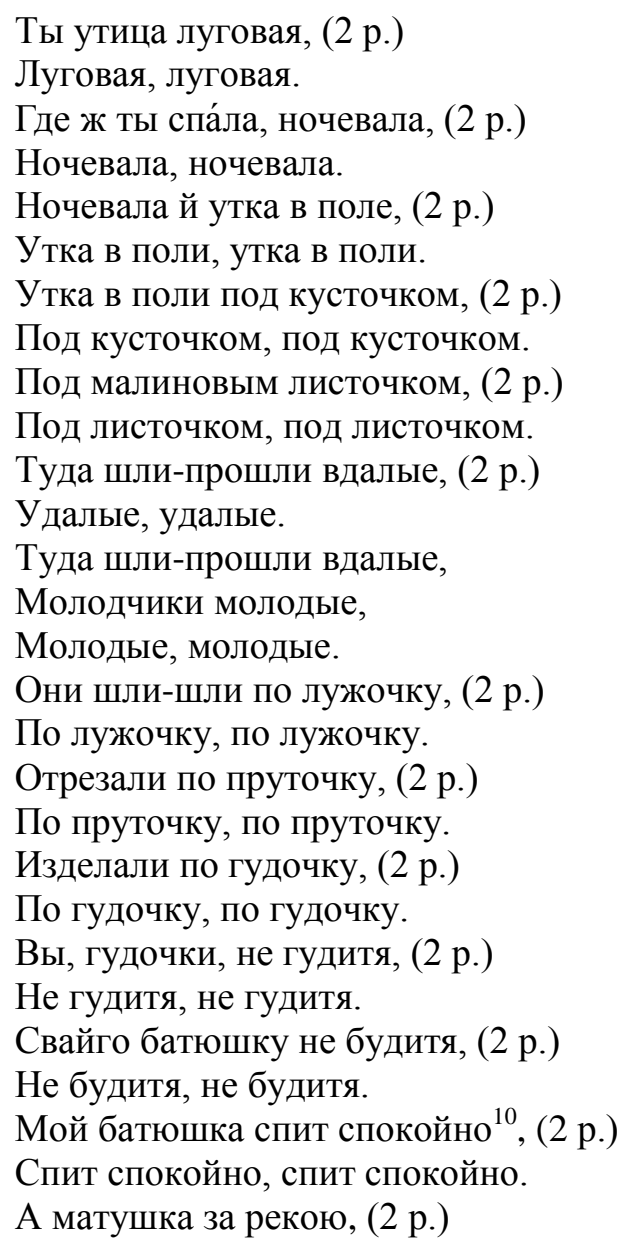

\footnotetext{
9 Эта же песня, с немного иным напевом, входит в радоницкий репертуар соседнего села Прямское.

10 Часть исполнительниц здесь пела вариант текста: «Мой батюшка спит с похмелья».
} 
За рекою, за рекою.

Пива гоня виравоя, (2. р.)

Виравоя, виравоя.

Дли зятюшки молодого, (2 р.)

Молодого, молодого.

Пей, зятюшка, не впевайся, (2 р.)

Не впевайся, не впевайся.

Дамой при́дешь, не ругайси, (2р.)

Не ругайси, не ругайси.

Исполнение первых трех куплетов вызвало обсуждение певческого стиля и многоголосной фактуры (в пении сделали паузу): «Ну яе ж красиво поют!» (Н.П. Ушакова), «Да, надо много [певцов], чтоб отво́дили (то есть пели на разные голоса. - T. Д.). Много басу́ють, штуки три помогають, а один звонко! Вот так надо. Одна надо, чтоб тоненько-тоненько, штуки три ишче (руками перед собой показывает, что речь идет о средних голосах) и басов многа. А кого тут ужо... (махнула рукой, мол, некому сейчас петь)» (Н.И. Дударева).

Хореографические особенности исполнения этого хоровода Н.И. Дударева описала так: «Вот беришь за руки вси, и как будто вокруг ёлки ходили хороводом. И вот ету жа [песню] пели, ето брались за плечи, как “'У середу на Масляную”, играли такую».

В теплое время года молодежь собиралась на улице, «на точке́». Там парни и девки пели, плясали, «в разлуку гуляли» (играли в игру под названием «разлука»), «в ремня гуляли, в красочки». Каждую игру информанты подробно описали и наглядно показали (есть видеозапись).

В заключение отметим, что в сёлах Прямское и Петропавловка, к сожалению, в настоящее практически нет молодежи, которая перенимала бы песни у старшего покаления. «Старые трошки шче вмеють [петь старинные песни]...» (Л.В. Гайдук). «А молодые не вмеють. И им не нравится, не любють [они такое пение], и смеются ли нас. Вот прыйдешь репетировать - [и будет] не так, всё не так» (Н.И. Дударева).

Однако в районном центре Маслянино существуют взрослый и детский фольклорные коллективы - «Горлинка» и «Жаворонушки» соответственно (руководитель Светлана Юрьевна Дукальская), в чьем исполнении песни Прямского и Петропавловки продолжают жить. Кроме того, в студии С.Ю. Дукальской в Маслянинском районном Доме культуры организован небольшой музей, где хранятся старинные предметы быта, домашний текстиль и традиционная одежда. Также имеется этнографический ткацкий станок в рабочем состоянии, на котором проводятся занятия по обучению искусству ткачества.

\section{Список информантов}

Чебакова Валентина Михайловна (в девичестве Гайдук), 1951 г. р., родилась в с. Петропавловка Маслянинского района Новосибирской области, в настоящее время проживает в г. Бердске.

Гайдук Любовь Васильевна (в девичестве Дударева), 1935 г. р., родилась в с. Петропавловка Маслянинского района Новосибирской области, русская, прадед переселился в Сибирь в начале XX в. из с. Батуровка Брянской области.

Дударева Надежда Ивановна (в девичестве Цыганок, девичья фамилия матери - Гайдук), 1947 г. р., родилась в с. Петропавловка Маслянинского района Новосибирской области, белоруска, бабушка родом из Черниговщины, а дед - из с. Клинцы Могилевской области.

Ушакова Надежда Павловна (в девичестве Филоненко), 1939-2017 гг., родилась в с. Петропавловка Маслянинского района Новосибирской области.

Андрюк Евдокия Терентьевна (в девичестве Науменко), 1927 г. р., родилась в с. Петропавловка Маслянинского района Новосибирской области, родители переселились в Сибирь из Украины.

\section{Список литературы}

Дайнеко Т.В. Календарные обряды и песни села Камышинка (материалы экспедиции 2016 г.) // Языки и фольклор коренных народов Сибири. 2016. № 2 (вып. 31). С. 85-91.

Дайнеко T.B. Календарные фольклорно-этнографические традиции белорусов Кыштовского района Новосибирской области // Вестн. Кемеров. гос. ун-та культуры и искусств. 2017. № 2 (39). С. 130 136. 
Леонова Н.В. Проблемы изучения фольклора белорусов Сибири // Гуманитарные науки в Сибири. 2000. № 3. C. 84-87.

Леонова Н.В. Белорусские фольклорные традиции в Сибири и на Дальнем Востоке // Фольклор белорусов Сибири и Дальнего Востока. Ч. 1: Семейно-обрядовые песни и причитания / Сост. Н.В. Леонова (отв. сост.) и др. Новосибирск: Наука, 2011. С. 12-34. (Памятники фольклора народов Сибири и Дальнего Востока; Т. 31).

Фурсова Е.Ф. Пути-дороги полевые... Из сибирских дневников Е.Ф. Фурсовой. Новосибирск: АртПресс, 2012. 72 с.

\section{T. V. Dayneko}

Institute of Philology of Siberian Branch of Russian Academy of Sciences, Novosibirsk, Russian Federation; tan-dai@mail.ru

\section{Notes from Petropavlovka: \\ according to the results of the expedition in 2016 to Maslyaninsky district of Novosibirsk region}

The paper contains a part of materials collected by the author in Petropavlovka village (Maslyaninsky district of Novosibirsk region) during the folklore-ethnographic expedition in 2016. Petropavlovka village was founded in 1907. At first the village was called Ukrop, by the name of the river flowing nearby; later it was renamed into Petropavlovka, by the names of the first builders, brothers Peter and Paul. The first inhabitants were peasants settlering from Byelorussia (mostly) and Ukraine, from Chernigovskaya province and the borderland of Bryansk-Smolensk region. Currently, Petropavlovka is a mixed type of settlements where Byelorussians and representatives of other ethnic groups live. The paper presents the transcription of the interview with the women dwelling in Petropavlovka village, who are descendants of the settlers from Byelorussia and border regions inheriting their folk tradition. The information about calendar rituals and songs of Petropavlovka is selected in the article. The information is compiled according the year calendar cycle that is reflected in the paper sections. According to informants, the Cristmastide (The Cristmas - New Year - Epiphany) in Petropavlovka village presented all the main ritual elements: walking from yard to yard singing carols, fortunetelling, evening parties of young people. The songs in this period include the time-connected genres: carols, childrens' recited waits. On Maslenitsa week the main ritual action was the burning of effigies. Humorous "maslenski" songs could be performed not only on Maslenitsa, but also on the second day of the wedding. The spring period in Petropavlovka village was represented by the Easter ritual complex. It also included ritual actions of the Radonitsa: a meal in a cemetery, singing troparions. Several round songs and "gukalnye" songs (they are almost gone now) were recorded in Petropavlovka village. The summer calendar period is marked by the feast of the Triniti Sunday. On the eve of the Triniti Sunday, the inhabitants of Petropavlovka went to the forest and torn the grass and flowers to decorate the home. The young people walked in the forest, swung on swings specially built to this day, the girls woven wreaths of flowers and herbs. The verbal texts of some songs from different calendar cycles are published in the paper. The aim of the paper is to introduce new materials on folklore of Byelorussian settlers to Siberia for scientific use.

Keywords: folklore of the Byelorussians of Siberia, calendar rituals and songs of the Siberian Byelorussian settlers, Maslyaninsky district of Novosibirsk region, fieldwork materials, field folklore study.

\section{References}

Dayneko T.V. Kalendarnye obryady i pesni sela Kamyshinka (materialy ekspeditsii 2016 goda) [Calendar Rituals and Songs of Kamyshinka Village (Fieldwork Materials of 2016)]. Yazyki i fol'klor korennykh narodov Sibiri [Languages and Folklore of Native Peoples of Siberia], 2016, no. 2 (iss. 31), pp. 85-91. (In Russ.).

Dayneko T.V. Kalendarnye fol'klorno-etnograficheskie traditsii belorusov Kyshtovskogo rayona Novosibirskoy oblasti [Calendar Folklore-Ethnographic Traditions of the Byelorussians of Kyshtovsky District, Novosibirsk Region]. Vestnik Kemerovskogo gosudarstvennogo universiteta kul'tury i iskusstv [Bulletin of Kemerovo State University of Culture and Arts], 2017, no. 2 (39), pp. 130-136. (In Russ.).

Leonova N.V. Problemy izucheniya fol'klora belorusov Sibiri [The problems of study of the Byelorussian Folklore of Siberia]. Gumanitarnye nauki v Sibiri [Humanities in Siberia]. 2000. no. 3. pp. 84-87. (In Russ.).

Leonova N.V. Белорусские фольклорные традиции в Сибири и на Дальнем Востоке. In: Fol'klor belorusov Sibiri i Dal'nego Vostoka. Chast'1. Semeyno-obryadovye pesni i prichitaniya. T. 13. Pamyatniki fol'klora narodov Sibiri i Dal'nego Vostoka [The Byelorussian Folklore of Siberia and the Far East. Part 1. Family Ritual Songs and Laments. Vol. 13. Monuments of Folklore of the Peoples of Siberia and Far-East]. Prepared by N.V. Leonova, T.G. Leonova, L.M. Sviridova, T.B. Varfolomeeva, K.P. Kabashnikov, A.S. Fedosik. Ed. V.M. Gatsak. Novosibirsk, Nauka Publ., 2011, pp. 12-34. (In Russ.).

Fursova E.F. Puti-dorogi polevye... Iz sibirskikh dnevnikov E.F. Fursovoy [The field way and roads... From the Siberian diaries of E.F. Fursova]. Novosibirsk, ArtPress Publ., 2012. 72 c. (In Russ.). 